\title{
The Innovation Gap between the Polish Economy and the European Union
}

\author{
Edyta Dworak \\ Ph.D., Professor at the University of Lodz, Faculty of Economics and Sociology \\ Department of Microeconomics \\ e-mail: edyta.dworak@uni.lodz.pl
}

\begin{abstract}
Knowledge and innovations are considered to be among the most important factors that determine the pace and quality of economic growth. Therefore, Poland is facing a serious challenge to effectively transform its economy into an innovative economy capable of competing with the most developed countries.

The aim of the paper is to present the results of analysis aimed at estimating the innovation gap between Poland and the European Union countries on the basis of the Summary Innovation Index (SII), which was developed by the European Commission within the European Innovation Scoreboard (EIS) in the years 2010-2018. It reviewed the literature on the innovativeness of economies and the innovation gap. Descriptive analysis, statistical data analysis and comparative analysis methods were applied. Statistical data from the European Innovation Scoreboard 2019 were used. The paper formulates a research thesis that assumes that the level of innovativeness of the Polish economy in the analyzed period remained at a lower level than the EU average and therefore there is still an innovation gap between the Polish economy and the average for European Union countries. The results of the analysis confirm this thesis.
\end{abstract}

Keywords: innovation, innovativeness, innovation gap, European Innovation Scoreboard (EIS), Summary Innovation Index (SII)

JEL: O30, O31, O33, O43 


\section{Introduction}

In developed market economies, a belief has developed that the ability of enterprises to create, apply and disseminate innovation is the most important manifestation of their modernity and an important premise for the civilization progress of the entire country. Many reputable economists present the view that the scope and pace of innovative processes are of great importance for the competitive advantage of enterprises and national economies (Porter 2001, pp. 215-216; Freeman 1982; Kotler 1999). The winners in the competitive game on a globalized market are those economies that have mastered the ability to quickly and efficiently transform the gains of scientific and technical thought into new or improved products, technologies and solutions in the area of organization and management. Knowledge and innovations are considered to be among the most important factors that determine the pace and quality of economic growth (Witkowska, Wysokińska 2006, pp. 23-24). Therefore, Poland is facing a serious challenge to effectively transform its economy into an innovative economy capable of competing with the most developed countries.

The aim of the paper is to present the results of analysis aimed at estimating theinnovation gap between Poland and the European Union countries on the basis of the Summary Innovation Index (SII), developed by the European Commission within the European Innovation Scoreboard (EIS) in the years 2010-2018. It reviewed literature on the innovativeness of economies and the innovation gap. Descriptive analysis, statistical data analysis and comparative analysis methods were applied. Statistical data from the European Innovation Scoreboard 2019 were used. The paper formulates a research thesis that assumes that the level of innovativeness of the Polish economy in the analyzed period remained at a lower level than the EU average and therefore there is still an innovation gap between the Polish economy and the average for European Union countries. The results of the analysis confirm this thesis.

\section{The concept of the innovation gap}

The concept of the innovation gap is variously interpreted in the economic literature. Kubielas defines the innovation gap as differences in the level of technological advancement between countries and proposes several methods to measure its size. He says that it can be measured by the distance between the level of technological activity of a country and the countries at the technological frontier, calculated either as a ratio of the number of patents per capita or the share of research expenditure in value-added or national income (Kubielas 2009, p. 137). The literature review also shows indirect measures such as the share of high-tech products in exports in relation to a similar indicator for the technology frontier, the relation of the productivity of a given branch of the country to the country on the verge of technological frontier or, in aggregate terms, the relationship between GDP per capita and the corresponding 
indicator of the technological frontier (Kubielas 2009, p. 137). The last two approaches identify the technological gap with a productivity gap or income gap. The global technological frontier shall be deemed as the GDP level, which can be achieved by using the given inputs of capital and labor, and the best possible technologies (Growiec 2012). This level of GDP is now achieved by the U.S. economy, in which, as stressed by Kubielas, the distribution of specialization (between Pavitt's four sectors) is the standard for a technology leader. The highest competitive advantages are demonstrated by the science-based sector, followed by the specialized supplier sectors; the scale-intensive and traditional are characterized by negative indices of the comparative advantage, of which the traditional is the lowest on the scale of advantages of the U.S. economy (Kubielas 2009, p. 153).

In the literature, there is also the concept of the innovation gap, understood as the distance between individual economies and the so-called modern technological frontier. It is identified with the last stage of the socio-economic development of economies, i.e., the emergence of a knowledge-based economy (Zacher 2007, p. 530; Pawlik 2014, pp. 68-69, National Systems of Innovation 1992, pp. 25-36). To investigate this approach to the innovation gap, one should use a point of reference, which involves the initial conditions of building a knowledge-based economy, as formulated by Kleer (Kleer 2009): (a) the economy must achieve a sufficiently high level of income (about $\$ 20,000$ per capita), and the structure of GDP should be characterized by a high share of services in GDP - 70\% or more; (b) society should be characterized by a high level of education, in which secondary education is widespread, and higher education covers at least half of the economically active population; (c) there should be a high share of expenditure on $\mathrm{R} \& \mathrm{D}$ (it is generally recognized that the size of the required outlays is about $3 \%$ of GDP); (d) the innovativeness of the economy manifests itself in minimizing regulations and supporting innovative projects, not only in purely economic areas, but also in high expenditure of the public sector on research that directly and indirectly promotes development; (e) the economy and society are involved in the exterior exchange, which concerns not only the exchange of goods and services, but also the circulation of ideas (for which the information revolution has created enormous opportunities); (f) the modern public sector needs to be a mixed model, and not purely liberal.

The United Nations defines the innovation gap quite generally, as the distance between those who have access to technologies and know how to use them effectively, and those who are not able to do it (Kraciuk pdf.). The innovation gap can be considered from the perspective of creating new technology in the home country, as well as from the perspective of its transfer from other countries and effectively adapting it to the needs and capabilities of the nation.

In summary, it can be stated that measuring the innovation gap means estimating the distance between a given country's economy and the most developed economies of Europe and the world, known today as knowledge-based economies, in many areas, e.g., in the sphere of innovation, education, and institutional system. Estimating the innovation gap is possible by comparing synthetic measures of innovation, e.g., 
the Summary Innovation Index developed by the European Commission, the Global Innovation Index developed by Cornell University (The Global Competitiveness Report 2018-2019) in cooperation with the World Intellectual Property Organization (Weresa 2014, p. 64; Mielcarek 2013), or indicators that describe the advancement of the knowledge-based economy, e.g., the Knowledge Index and the Knowledge Economy Index, derived from the Knowledge Assessment Methodology.

\section{Assessing the innovation gap between the Polish economy and the European Union countries based on the Summary Innovation Index}

Innovation measurements are made based on various methods and measures. One such method is the European Innovation Scoreboard, developed by the European Commission. The European Innovation Scoreboard has been published since 2000, and it is an attempt to estimate the achievements of innovative European economies based on the SII. It is estimated using weighted values of normalized data, with the highest value of the indicator in the examined group of countries equaling 1 and the lowest value equaling 0 . Based on this indicator, four groups of $E U$ economies that show different levels of innovativeness can be distinguished: innovation leaders - which present the highest level of innovativeness of the economy, innovation followers, moderate innovators, and modest innovators.

This paper presents an attempt to estimate the innovation gap based on the indicator that shows the difference between the level of the SII for Poland and the average value of this index for the European Union. The indicator of the innovation gap defined in this way takes the following form (Weresa 2014, p. 64):

$$
L_{p t}=\frac{S I I_{p t}}{S I I_{U E_{t}}},
$$

where:

$L_{p t}$ - the innovation gap index for Poland in relation to the EU average in year $\mathrm{t}$, $S_{\text {IIt }}$ - the Summary Innovation Index for Poland in year $\mathrm{t}$, $S I I_{U E t}$ - the average Summary Innovation Index for the EU in year $\mathrm{t}$.

The value of the innovation gap index exceeding 1 means that the analyzed country presents a higher level of innovativeness than the EU average, while a value lower than 1 indicates the innovation gap exists between a given country and the EU average.

In order to assess the changes in the level of the innovation gap over time, a formula presenting the difference between the innovation gap index $\left(L_{p t}\right)$ in a given year and the value of this index for the previous year should be used. It is written as follows (Weresa 2014, p. 64): 
The Innovation Gap between the Polish Economy and the European Union

$$
D t_{1}=\left[\frac{S I I_{p t_{1}}}{S I_{u e t_{1}}}\right]\left[\left[\frac{S I I_{p t}}{S I I_{u e t}}\right],\right.
$$

where:

$D_{p t_{1}}$ - index of changes in the level of the innovation gap between Poland and the EU average in year $t 1$ compared to year $t$,

$S_{\text {pt }}$ - the Summary Innovation Index for Poland in year $t$,

$S I I_{u e t}$ - the average Summary Innovation Index for the EU in year $\mathrm{t}$,

$S I I_{p t_{1}}$ - the Summary Innovation Index for Poland in year $\mathrm{t} 1$,

$S I I_{U E t_{1}}$ - the average Summary Innovation Index for the EU in year $\mathrm{t} 1$.

The index of the change in the innovation gap level $\left(D_{p t_{1}}\right)$ takes values from -1 to +1 . Negative values indicate an increase in the innovation gap between a given country and the EU average, while positive ones indicate a decrease. Nevertheless, it should be emphasized that the analyzed index only indicates the direction of changes, but it does not allow us to determine whether the distance shortens or the previously gained advantage is gradually being lost (Weresa 2014, p. 65). Therefore, it is necessary to analyze the index of changes in the level of innovation gap $\left(D_{p t_{1}}\right)$ in relation to the index of the innovation gap $\left(L_{p t}\right)$.

Table 1 shows the values of the Summary Innovation Index for Poland and the average value for $28 \mathrm{EU}$ countries, the values of the innovation gap index for Poland in relation to the EU average $\left(L_{p t}\right)$, and the index of changes in the level of the innovation gap between Poland and the EU average $\left(D_{p t_{1}}\right)$ in the years 2010-2018.

Table 1. The Summary Innovation Index for Poland and the average value for 28 EU countries, the innovation gap index for Poland in relation to the $\mathrm{EU}$ average $\left(L_{p t}\right)$, and the index of changes in the level of the innovation gap between Poland and the EU average $\left(D_{p t_{1}}\right)$ between 2010 and 2018

\begin{tabular}{|l|c|c|c|c|c|c|c|c|c|}
\hline \multicolumn{1}{|c}{ Index } & 2010 & 2011 & 2012 & 2013 & 2014 & 2015 & 2016 & 2017 & 2018 \\
\hline SIl for the EU & 0.493 & 0.482 & 0.478 & 0.483 & 0.482 & 0.490 & 0.503 & 0.513 & 0.525 \\
\hline SII for Poland & 0.261 & 0.257 & 0.242 & 0.252 & 0.242 & 0.248 & 0.260 & 0.273 & 0.295 \\
\hline$L_{p t}$ for Poland & 0.529 & 0.533 & 0.506 & 0.522 & 0.502 & 0.506 & 0.516 & 0.530 & 0.560 \\
\hline $\begin{array}{l}D_{p t_{1}} \text { compared } \\
\text { to the previous } \\
\text { year }\end{array}$ & - & 0.04 & -0.027 & 0.016 & -0.02 & 0.004 & 0.01 & 0.014 & 0.03 \\
\hline $\begin{array}{l}D_{p t_{1}} \text { compared } \\
\text { to 2010 }\end{array}$ & - & 0.04 & -0.023 & -0.007 & -0.02 & -0.023 & -0.013 & 0.001 & 0.031 \\
\hline
\end{tabular}

Source: own calculations based on the European Innovation Scoreboard 2019, www.proinno-europe.eu /metrics (accessed: 7.08.19).

The analysis of the innovation gap index for Poland $\left(L_{p t}\right)$ indicates that throughout the entire analyzed period, the level of innovativeness of the Polish economy was below the EU average. Based on the index of changes in the level of the innovation gap $\left(D_{p t_{1}}\right)$, it can be concluded that in 2012 and 2014, the difference between the level of innovativeness of the Polish economy and the EU average increased compared to the previous 
year. Meanwhile, the index of changes in the level of the innovation gap $\left(D_{p t_{1}}\right)$ in 2018 compared to 2010 showed positive values -0.031 , which indicates a decrease in the distance between the innovative position of the Polish economy and the EU average (it was similar in 2011 and 2017). When estimating the level of innovativeness of the Polish economy, it is also worth comparing Poland's innovative position in relation to individual European Union countries over time. Table 2 shows the values of the SII for all European Union countries in 2010 and 2018. Based on the value of the index, the innovation gap index $\left(L_{p t}\right)$ for the Polish economy in 2010 and 2018 in relation to other EU countries was calculated, as well as the index of changes in the level of the innovation gap $\left(D_{p t_{1}}\right)$ between Poland and another EU country in 2018, compared to 2010. The following assumptions should be made for this analysis:

$$
L_{p t}=\frac{S I I_{p t}}{S I I_{m t}}
$$

where:

$L_{p t}$ - the index of the innovation gap for Poland in year $\mathrm{t}$, $S I I_{p t}$ - the Summary Innovation Index for Poland in year t, $S I I_{m t}$ - the Summary Innovation Index for the EU country in year $\mathrm{t}$, and

$$
D_{p t_{1}=\left[S I_{p_{1}}\right]-\left[\frac{S I I_{m t}}{S I_{m t}}\right]},
$$

where:

$D_{p t_{1}}$ - the index of changes in the level of innovation gap for Poland vs. another EU country in year $\mathrm{t} 1$ compared to year $\mathrm{t}$,

$S I I_{p t}$ - the Summary Innovation Index for Poland in year $\mathrm{t}$,

$S I I_{m t}$ - the Summary Innovation Index for the EU country in year $\mathrm{t}$,

$S I_{p t_{1}}$ - the Summary innovation index for Poland in year t1,

$S I I_{m t_{1}}$ - the Summary innovation index for the EU country in year t1.

Table 2. The Summary Innovation Index for European Union countries in 2010 and 2018, the innovation gap index for the Polish economy in relation to the EU country $\left(L_{p t}\right)$ in 2010 and 2018 , and the index of changes in the level of the innovation gap between Poland and the EU country $\left(D_{p t 1}\right)$ in 2018 compared to 2010

\begin{tabular}{|l|c|c|c|c|c|}
\hline \multicolumn{1}{|c|}{ Country } & SSI in 2010 & $L_{p t}$ in 2010 & SII in 2018 & $L_{p t}$ in 2018 & $\begin{array}{c}D_{p t_{1}} \text { compared } \\
\text { to } 2010\end{array}$ \\
\hline Belgium & 0.590 & 0.442 & 0.618 & 0.477 & 0.035 \\
\hline Bulgaria & 0.234 & 1.115 & 0.235 & 1.255 & 0.14 \\
\hline Czech Republic & 0.434 & 0.601 & 0.431 & 0.684 & 0.083 \\
\hline Denmark & 0.688 & 0.379 & 0.680 & 0.433 & 0.054 \\
\hline
\end{tabular}




\begin{tabular}{|l|c|c|c|c|c|}
\hline \multicolumn{1}{|c|}{ Country } & SSI in 2010 & $L_{p t}$ in 2010 & SII in 2018 & $L_{p t}$ in 2018 & $\begin{array}{c}D_{p t_{1}} \text { compared } \\
\text { to } 2010\end{array}$ \\
\hline Germany & 0.627 & 0.416 & 0.618 & 0.477 & 0.061 \\
\hline Estonia & 0.411 & 0.635 & 0.500 & 0.590 & -0.045 \\
\hline Ireland & 0.554 & 0.471 & 0.567 & 0.520 & 0.049 \\
\hline Greece & 0.333 & 0.783 & 0.394 & 0.748 & -0.035 \\
\hline Spain & 0.395 & 0.660 & 0.409 & 0.721 & 0.061 \\
\hline France & 0.525 & 0.497 & 0.535 & 0.551 & 0.054 \\
\hline Croatia & 0.277 & 0.942 & 0.287 & 1.027 & 0.082 \\
\hline Italy & 0.372 & 0.701 & 0.410 & 0.704 & 0.003 \\
\hline Cyprus & 0.432 & 0.604 & 0.419 & 0.704 & 0.100 \\
\hline Latvia & 0.244 & 1.069 & 0.370 & 0.797 & -0.272 \\
\hline Lithuania & 0.288 & 0.906 & 0.391 & 0.754 & -0.152 \\
\hline Luxembourg & 0.592 & 0.440 & 0.623 & 0.473 & 0.033 \\
\hline Hungary & 0.350 & 0.740 & 0.333 & 0.885 & 0.145 \\
\hline Malta & 0.318 & 0.820 & 0.413 & 0.714 & -0.106 \\
\hline Netherlands & 0.588 & 0.443 & 0.651 & 0.453 & 0.01 \\
\hline Austria & 0.555 & 0.470 & 0.602 & 0.490 & 0.02 \\
\hline Portugal & 0.421 & 0.619 & 0.471 & 0.626 & 0.007 \\
\hline Romania & 0.236 & 1.105 & 0.165 & 1.787 & 0.682 \\
\hline Slovenia & 0.483 & 0.540 & 0.423 & 0.697 & 0.157 \\
\hline Slovakia & 0.306 & 0.852 & 0.333 & 0.885 & 0.033 \\
\hline Finland & 0.671 & 0.388 & 0.704 & 0.419 & 0.031 \\
\hline Sweden & 0.697 & 0.374 & 0.713 & 0.413 & 0.039 \\
\hline United Kingdom & 0.560 & 0.466 & 0.616 & 0.478 & 0.012 \\
\hline
\end{tabular}

The SII for Poland in 2010 was 0.261; in 2018, it was 0.295.

Source: own calculations based on the European Innovation Scoreboard 2019, www.proinno-europe.eu /metrics (accessed: 8.07.2019).

Based on the data presented in Table 2, it can be stated that in 2010, the Polish economy showed higher innovation potential than the economies of three EU countries - Bulgaria, Latvia, and Romania (the $L_{p t}$ index was above 1). In 2018, the level of innovativeness of the Polish economy was higher than that of Bulgaria, Romania, and Croatia. Therefore, it is worth emphasizing that the innovative position of the Polish economy was lower not only in relation to the "old" member states of the European Union, but also to the majority of "new" EU member states. ${ }^{1}$ However, it should be noted that between 2010 and 2018, the innovation gap between the Polish economy and most EU countries decreased. Only in relation to a few countries (Estonia, Greece, Latvia, Lithuania, and Malta) did this distance increase.

1 Those countries which joined the EU in 2004 and later. 


\section{Remarks and recommendations}

In the 2015 EIS ranking, Poland was included in the group of moderate innovators, which means that it had improved its position in relation to previous years; however, it was still in the "tail-end" of the group. In the overall EIS statement, Poland ranked $25^{\text {th }}$ and has not improved its position since then. This fact and the analysis of the innovation distance between the Polish economy and the EU countries allow us to conclude that the effects of the innovation policy pursued so far are small. It is, therefore, necessary to make an effort to reconstruct the existing model of supporting the development of innovation in Poland. The success of this project depends on many different factors which affect not only the sphere of economic policy but also social and cultural conditions.

Firstly, it is important to raise the level of innovativeness of the Polish economy, bridging the innovation gap in relation to most EU countries, and formulate a longterm strategy for socio-economic development. Without such a strategy it is not possible to pursue an internally coherent and consistent policy for the development of science and technology, which would decide on the development directions of scientific research and technology areas preferred by the state, allowing the use of the national potential and achievements of Polish inventors (Dworak 2012, p. 219).

Secondly, the development of innovation requires a well-functioning institutional system. An appropriate institutional order affects the utilization of the economy's technological potential. Empirical studies confirm the existence of a positive, statistically significant correlation between the degree of development of the economy and the efficiency of the State's systemic activities in developing the institutional order. ${ }^{2}$ The institutional environment includes an important element, a widely understood business environment, which facilitates the development of entrepreneurship and innovation. This means, among others, the need to simplify administrative and judicial procedures.

Thirdly, the creation of an effective system for promoting innovation requires an increased and adequate allocation of financial outlays on R\&D and implementation, coming from the state budget and industry (Orłowski 2013, p. 10). Changes in this area should primarily involve increasing industry expenditure on $\mathrm{R} \& \mathrm{D}$ by facilitating access to capital in all phases of R\&D projects (Dworak 2012, p. 221; Gorynia-Pfeffer 2012, p. 216). Budgetary outlays on R\&D should also be increased, provided that the R\&D investments of private enterprises also increase (Okoń-Horodyńska 2004, p. 33).

Fourthly, to significantly raise the level of innovativeness of the economy, it is necessary to develop permanent links between the entities of the R\&D sphere and industry. Building a close relationship between R\&D institutions and enterprises should focus on the development of projects involving support for: (a) the movement of personnel between $R \& D$ institutions and the economy, including internships of $R \& D$ workers

2 The study included the OECD countries in the years 2001-2005 (Balcerzak 2009, pp. 231-241). 
in enterprises and employees of enterprises at universities; (b) cooperation within the clusters, which increase the ability of operators to create, absorb, and diffuse innovation (Skawińska, Zalewski 2009, pp. 173-181, 254-260); (c) the establishment and development of institutions in the innovative environment, such as technological incubators, technology transfer centers, and science and technology parks.

Fifthly, what is crucial for financing firms' innovative projects is the development of the private equity and venture capital market (Gasz 2015, p. 221). The existing involvement of private equity funds or venture capital funds in financing this type of activity in Poland is insufficient (European Innovation Scoreboard 2019, p. 83). ${ }^{3}$ The development of the public-private partnership system in financing strategic technologies creates opportunities to overcome barriers to the capital, which now discourages companies, especially small and medium-sized enterprises, from undertaking innovation (Raport o partnerstwie publiczno-prywatnym w Polsce 2013).

Sixthly, the education system is an important pillar of the strategy for improving innovativeness. It focuses on developing creativity and the ability to work together. The efficient use of human capital requires an increase in social capital (Raport o partnerstwie publiczno-prywatnym $w$ Polsce 2013, p. 37). The indicators that characterize this capital in Poland are currently the lowest in the European Union. According to a study in the framework of "Social Diagnosis 2013," only 14\% of Poles trust other people, with an average confidence level of 32\% in the European Union (Diagnoza społeczna 2013; Warunki i jakość życia 2014, p. 320).

\section{Conclusions}

The experience of the economies that joined the group of innovation leaders in recent decades shows that supporting the development of innovation is a long-term activity and requires that many conditions be met. In the context of considerations on the innovativeness of the Polish economy, it must, therefore, be stated that a necessary condition for its increase is the formulation of a long-term strategy for the innovation policy that takes into account the real potential of the economy at its current stage of development. It seems reasonable to assume that in the near future Poland should implement a strategy based on a specific version of the imitation model. Therefore, catching up in the area of research and innovation should be possible thanks to the transfer of knowledge and innovation, mainly through foreign direct investment.

A necessary prerequisite for the effectiveness of this solution, however, is the introduction of regulations that will cause foreign companies to locate in Poland not only the production cycle but also elements of the value chain related to R\&D. It should be added that the transfer of new technologies through direct investment requires

3 Venture capital investments in relation to GDP accounted for $0.054 \%$, and the average rate for the European Union was 0.149\%. European Innovation Scoreboard 2019, www.proinno-europe.eu /metrics, 2019, p. 83. 
a company's own R\&D facilities and educated engineering and technical employees, as well as financing the development of imported technologies. However, it should be remembered that the application of the imitation strategy may be limited e.g., due to limited access to technology. Therefore, it is necessary for native R\&D institutions to generate innovation. The Polish economy should selectively move to the group of technological leaders, searching for niches in those areas of science and technology that are Polish specialties and have a chance to achieve market success.

\section{References}

Balcerzak, A. (2009), Państwo w realiach „nowej gospodarki”, Wydawnictwo Adam Marszałek, Toruń.

Diagnoza społeczna 2013. Warunki i jakość życia (2014), Czapiński J., Panek F. (eds.), Warszawa.

Dworak, E. (2012), Gospodarka oparta na wiedzy w Polsce. Ocena, uwarunkowania, perspektywy, Wydawnictwo Uniwersytetu Łódzkiego, Łódź.

European Innovation Scoreboard (2019), http://www.proinno-europe.eu/metrics (accessed: 20.07.2019).

Freeman, Ch. (1982), The Economics of Industrial Innovation, F. Pinter, London.

Gasz, M. (2015), Kierunki zmian w polityce innowacyjnej w Polsce i Unii Europejskiej, "Studia Ekonomiczne. Zeszyty Naukowe Uniwersytetu Ekonomicznego w Katowicach", 214.

Gorynia-Pfeffer, N. (2012), Wybrane aspekty działalności innowacyjnej na przykładzie Niemiec-wnioski dla Polski, "Studia Ekonomiczne", 2.

Growiec, J. (2012), Zagregowana funkcja produkcji w ekonomii wzrostu gospodarczego $i$ konwergencji, Oficyna Wydawnicza SGH, Warszawa.

Kleer, J. (2009), Gospodarka oparta na wiedzy a globalizacja: związki czasowe czy przyczynowe [in:] Kotowicz-Jawor, J. (ed.), GOW - wyzwanie dla Polski, PTE, VIII Kongres Ekonomistów Polskich, Warszawa.

Kotler, Ph. (1999), Marketing narodów, Profesjonalna Szkoła Biznesu, Kraków.

Kraciuk, J. (2006), Korporacje transnarodowe a zjawisko luki technologicznej w krajach rozwijajacych się, "Zeszyty Naukowe SGGW - Ekonomika i Organizacja Gospodarki Żywnościowej”, 61.

Kubielas, S. (2009), Innowacje i luka technologiczna $w$ gospodarce globalnej opartej na wiedzy. Strukturalne i makroekonomiczne uwarunkowania, Uniwersytet Warszawski, Wydział Nauk Ekonomicznych, Warszawa.

Mielcarek, P. (2013), Luka innowacyjności polskiej gospodarki względem Unii Europejskiej, “Zeszyty Naukowe Uniwersytetu Szczecińskiego, Finanse, Rynki finansowe, Ubezpieczenia Nr 57”, 756.

National Systems of Innovation (1992), Lundvall B.-A. (ed.), Printer Publishers, London. Okoń-Horodyńska, E. (2004), Co z Narodowym Systemem Innowacji w Polsce?, [in:] Okoń-Horodyńska, E. (ed.), Rola polskiej nauki we wzroście innowacyjności gospodarki, Polskie Towarzystwo Ekonomiczne, Warszawa. 
Orłowski, W.M. (2013), Komercjalizacja badań naukowych w Polsce. Bariery i możliwości ich przełamania, PWC, Warszawa, lipiec 2013.

Pawlik, A. (2014), Dystans innowacyjny województw, Wydawnictwa Uniwersytetu Jana Kochanowskiego, Kielce.

Porter, M. (2001), Porter o konkurencji, PWE, Warszawa.

Raport o partnerstwie publiczno-prywatnym w Polsce, (2013), Hausner, J. (ed.), Centrum Partnerstwa Publiczno-Prywatnego, Warszawa, lipiec.

Skawińska, E., Zalewski, R.I. (2009), Klastry biznesowe w rozwoju konkurencyjności i innowacyjności regionów. Świat-Europa-Polska, PWE, Warszawa.

The Global Competitiveness Report 2018-2019, Schwab, K. (ed.), World Economic Forum, Geneva.

Weresa, M.A. (2014), Polityka innowacyjna, Wydawnictwo Naukowe PWN SA, Warszawa.

Witkowska, J., Wysokińska, Z. (2006), Umiędzynarodowienie małych i średnich przedsiębiorstw a procesy integracji europejskiej. Aspekty teoretyczne i empiryczne, Wydawnictwo Uniwersytetu Łódzkiego, Łódź.

Zacher, L. (2007), Transformacje społeczeństw od informacji do wiedzy, C.H. Beck, Warszawa.

\section{Streszczenie}

\section{Luka innowacyjna między polską gospodarką a Unią Europejską}

Wiedza i innowacje są uznawane za jeden z najistotniejszych czynników determinujących tempo i jakość wzrostu gospodarczego. Przed Polską staje poważne wyzwanie efektywnego przekształcenia jej gospodarki w gospodarkę innowacyjną, zdolną do konkurowania z najbardziej rozwiniętymi krajami.

Celem artykułu jest oszacowanie luki innowacyjnej między Polską a krajami Unii Europejskiej na podstawie sumarycznego indeksu innowacyjności, opracowanego przez Komisję Europejską w ramach European Innovation Scoreboard (Europejskiej Tablicy Innowacji) w latach 2010-2018. Dokonano w nim przeglądu literatury na temat innowacyjności gospodarek i luki innowacyjnej. Zastosowano metody analizy opisowej, analizy danych statystycznych w czasie i analizy porównawczej. W badaniu wykorzystano dane statystyczne pochodzące z European Innovation Scoreboard 2019. W artykule sformułowano tezę badawczą, która zakłada, że w analizowanym okresie poziom innowacyjności polskiej gospodarki utrzymuje się na niższym poziomie od średniej unijnej, a zatem wciąż istnieje luka innowacyjna między polską gospodarką a średnią dla krajów Unii Europejskiej. Wyniki przeprowadzonej analizy potwierdzają tę tezę.

Słowa kluczowe: innowacja, innowacyjność, luka innowacyjna, Europejska Tablica Innowacji, sumaryczny indeks innowacji 